\section{The influence of knowledge and attitude of female adoles- cents on Fe tablet consumption at Public Senior High School 1 of Gorontalo City, Indonesia}

\author{
Zuriati Muhammad, ${ }^{1,2}$ Sri Sumarmi ${ }^{3}$ \\ ${ }^{1}$ Doctoral Program of Public Health, \\ Faculty of Public Health, Universitas \\ Airlangga; ${ }^{2}$ Universitas Muhammadiyah \\ Gorontalo; ${ }^{3}$ Faculty of Public Health, \\ Airlangga University, Surabaya, \\ Indonesia
}

\begin{abstract}
Female undergo menstruation, pregnancy and breastfeeding, which bring about the need to consume blood cell tablet in order to provide extra iron and further replace lost blood, as a preparation through adolescence. Furthermore, females tend to suffer from anemia, exhibit retarded learning, working competence, quality of human resources and overall wellbeing of their offspring hence the promotion of nutritional status and health is essential (Warsiti, 2013). This study therefore aims to investigate the effect of knowledge and attitudes of female adolescents on the consumption of Fe tablet at Public Senior High School 1 of Gorontalo, applying a quantitative approach with cross-sectional method. With a sample of 72 students, the study involved the use of a questionnaire to obtain data, which were analyzed using the Fisher Ex cact (X2) test at the significance level of 95\% ( $\alpha=0.05)$. The analysis results revealed no influence of knowledge, toward the behavior of consuming Fe tablet with $\mathrm{p}$-value $=0.355$. Furthermore, there was a correlation between attitudes and consumption behavior, with $\mathrm{p}$-value $=0.003$ among young women in Public Senior High School.
\end{abstract}

\section{Introduction}

Blood cell pills are iron-folate tablets, which contains $200 \mathrm{mg}$ of Ferrous Sulphate or $60 \mathrm{mg}$ of Iron Element and $0.25 \mathrm{mg}$ of Folic Acid. Furthermore, females need this medication, for the replacement of lost blood because of menstruation, pregnancy and breastfeeding they endure. This is therefore the reason for adopting early preparation, from the incidence of puberty. Females who suffer from anemia, exhibit disruption in learning skills, work competence, quality of human resources as well as the overall wellbeing of their offspring, therefore upgrading their nutritional status and health is important. ${ }^{1,2}$

The Indonesian government has implemented efforts to tackle problems associated with anemia in adolescents, through the reinforcement of consuming blood tablet supplementation (known as TTD). Furthermore, since 1997, they have also pioneered novel initiatives to prevent and overcome the nutritional issues in women of reproductive age (WRA), by administering treatment at an earlier age (adolescence), conversely, its aim was to support efforts geared towards curtailing maternal mortality rate (MMR), through the reduction of the risk of bleeding, due to anemia in pregnant women, however, this intervention has been proven unsuccessful. ${ }^{3}$

It is recommended that the consumption of iron tablet in the form of blood cell tablets, containing $60 \mathrm{mg}$ iron and $2.8 \mathrm{mg}$ folic acid. This is highly recommended for WRAs having their period, to consume the remedy once a week for 2 weeks, with a gap of 3 months, therefore, totaling 24 tablets per year. Some studies have established the effect of iron supplementation on elevated hemoglobin levels. Weekly supplementation results in the same increase in hemoglobin in comparison with daily administration and during menstruation, which is rational because intestinal cell turnover takes place every 5-6 days and there is also limited iron intake capacity. ${ }^{4}$

According to the World Health Organization (WHO, 2013), iron deficiency triggered anemia is a crucial health problem, throughout the world, especially in developing countries and it was estimated that $30 \%$ of the universal population suffer from anemia. Furthermore, it occurs at a higher rate in the community among young ladies, with a high incidence and also, pregnant women.

In Indonesia, records have shown a decrease in the prevalence of anemia in young women, based on data from the 2004 household health survey (known as SKRT), which illustrated the highest incidence of deficiency anemia, was found in girls aged $10-18$ years at $57.1 \%$, compared to $50.5 \%$ in pregnant females and $45.1 \%$ in postpartum women. Furthermore, the data also showed the degree of anemia in women ( $\geq 15$ years) and reported the incidence of anemia at $19.7 \%$ at the national level and the research, established that its proportion, in young women (15-24 years) was $18.4 \% .^{5,6}$ According to previous research, despite the decline, through 2010 to 2013, there was still a high incidence of anemia in young women, considered to pose serious health risks, since the occurrence is over
Correspondence: Zuriati Muhammad, Doctoral Program of Public Health, Faculty of Public Health, Universitas Airlangga, Jl. Mulyorejo, Surabaya, Jawa Timur 60115, Indonesia.

Tel: +62315920948 -Fax: +62315924618 .

E-mail: zuriati.muhamad-2017@fkm.unair.ac.id, zuriatimuhamad@umgo.ac.id.

Key words: Fe Tablet, consumption behavior, knowledge, attitude.

Contributions: the authors contributed equally.

Conflict of interests: no potential conflict of interests.

Funding: none.

Clinical trials: the study is not involved any clinical trials.

Conference presentation: part of this paper was presented at the $3^{\text {rd }}$ International Symposium of Public Health, 2018 October 31- November 1, Universitas Airlangga, Surabaya, Indonesia.

Received for publication: 28 July 2019.

Revision received: 9 September 2019.

Accepted for publication: 15 October 2019.

This work is licensed under a Creative Commons Attribution NonCommercial 4.0 License (CC BY-NC 4.0).

CC Copyright: the Author(s), 2019

Licensee PAGEPress, Italy

Journal of Public Health in Africa 2019; 10(s1):1201 doi:10.4081/jphia.2019.1201

$15 \% .^{6}$ The negative impact of iron deficiency in growing adolescents includes suboptimal growth and development, reduced rate of learning because of exhaustion and it is also affiliated with decreased energy and concentration. Conversely, the long-term impact of anemia, especially in teenage pregnancy, is death as it is a risk factor for bleeding during childbirth, which is a direct cause of maternal death $(28 \%){ }^{3}$

The knowledge influences attitudes and behaviors, towards the choice of food and consumption of $\mathrm{Fe}$ supplements during menstruation, this are factors, which influence nutritional problems in adolescents. Furthermore, the awareness and understanding the individuals' nutrient state, including anemia status also play a role. ${ }^{1,7}$

The strategy adopted to overcome this problem in young women involves improving feeding habits, food fortification and administering $\mathrm{Fe}$ supplements, which are important on a long-term basis, however, this is not expected to facilitate immediate 
success. ${ }^{8}$ Another alternative therefore is to provide $\mathrm{Fe}$ additive, through the administration of blood-supplemented tablet as this is an efficient and cost effective way because it is easy to get and it also leads to immediate effects. Brabin and brain recommend anemia prevention programs with more supplementation of $\mathrm{Fe}$, targeted on young women, rather than children, adult women/pregnant women because it generates a more significant impact on reproductive health and also the success of the procreation process, when compared to its provision, only during pregnancy. Young ladies are prospective mothers, needed to be healthy and well protected from this condition, which is vital to ensure the birth of healthy babies..$^{8,9}$ To improve the quality of WRA resources, it is necessary to repair their iron status to ensure the accomplishment of the pregnancy period in a healthy condition. A study conducted by Bestaet et al. and Husaini et al., concludes that the performance of workers with a rapid relapse of anemia, increased due to iron supplementation. INACG therefore suggested that WRAs, who are not pregnant, also need to be given an additive, containing $60 \mathrm{mg}$ of iron, accompanied by $400 \mathrm{mg}$ of folate as a measure to prevent problems during pregnancy in future. ${ }^{10}$

Gorontalo City Health Office implemented a program for administering these tablets in every school, located in Gorontalo City, to support the efforts to maximize nutrition improvement sustainably and therefore anticipate the increasing incidence of iron nutrition anemia in young women. Furthermore, the rate of success has however remained unknown, thus further research needs to be carried out. ${ }^{6}$

\section{Materials and Methods}

This research deployed a quantitative approach, with a cross-sectional method, on a sample size of 72 young women, at Public Senior High School 1 of Gorontalo from July 10 to September 30 . The subjects were however, determined by stratified random sampling.

\section{Results}

The results show the influence and attitude on the $\mathrm{Fe}$ consumption behavior as seen on Tables 1 and 2 .

Table 1 shows that 66 female students $(51.7 \%)$ have good knowledge and do not consume Fe tablet, while 11 female students $(15.5 \%)$ have good knowledge and consume Fe tablet. Also, those with fair knowledge and poor knowledge comprise of $5.6 \%$ and $2.8 \%$ of the total sample, respectively. The results of the statistical test indicate $0.355>0.05$, which means that there is no influence between the knowledge of young women and the $\mathrm{Fe}$ tablet consumption behavior among young women at Public Senior High School 1 of Gorontalo.

Table 2 illustrates that 27 female students $(37.5 \%)$ have good attitudes, howev- er, they do not consume Fe tablet. 10 female others $(13.9 \%)$ possess good attitudes and also consume this tablet. 28 female students $(38.9 \%)$ have a fair attitude and they do not utilize it. Furthermore, this study disclosed that only 1 female student $(1.4 \%)$ has poor attitudes to Fe tablet consumption.

\section{Discussion}

The Influence of Female Adolescents' knowledge on the $\mathrm{Fe}$ Consumption Behavior

The results of the study at Public Senior High School 1 of Gorontalo, demonstrated that 66 students $(91.7 \%)$ of 72 respondents have sufficient knowledge of the drug, however, only 11 consumed it, with a $\mathrm{P}$ value of $0.355>\alpha=0.05$, which indicates that there is no influence between the knowledge variables on the behavior of Fe tablet consumption. The results further pointed out that $76.4 \%$ of the students have good knowledge about the tablet, yet they did not consume it.

Based on the analysis results, $76.4 \%$ of the subject, who were well-informed, do not consume the tablet, which was probably due to the lack of self-awareness of adolescence and internal factors, including emotions, mental habits and the ability to properly choose food. These findings are in line with the theory proposed by Notoatmodjo which pointed out that behavior is not only influenced by knowledge, but also by external elements, such as the environment and other internal factors, including intelligence, per-

Table 1. The influence of knowledge on the Fe Consumption Behavior.

\begin{tabular}{|c|c|c|c|c|c|c|c|}
\hline \multirow[t]{3}{*}{ Knowledge } & \multicolumn{4}{|c|}{ Fe Tablet Consumption } & \multicolumn{2}{|c|}{ Total } & \multirow[t]{3}{*}{ P Value } \\
\hline & \multicolumn{2}{|c|}{ With Consumption } & \multicolumn{2}{|c|}{ Without Consumption } & & & \\
\hline & $\mathbf{F}$ & $\%$ & $\mathbf{F}$ & $\%$ & $\mathbf{F}$ & $\%$ & \\
\hline Good & 55 & $76.4 \%$ & 11 & $15,3 \%$ & 66 & $91.7 \%$ & 0.355 \\
\hline Fair & 4 & $5.6 \%$ & 0 & $0 \%$ & 4 & $5.6 \%$ & \\
\hline Poor & 2 & $2.8 \%$ & 0 & $0 \%$ & 2 & $2.8 \%$ & \\
\hline Total & 61 & $84.7 \%$ & 11 & $15.3 \%$ & 72 & $100 \%$ & \\
\hline
\end{tabular}

Table 2. The influence of attitude on the Fe Consumption Behavior.

\begin{tabular}{|c|c|c|c|c|c|c|c|}
\hline \multirow[t]{3}{*}{ Attitude } & \multicolumn{4}{|c|}{ Fe Tablet Consumption } & \multicolumn{2}{|c|}{ Total } & \multirow[t]{3}{*}{ P Value } \\
\hline & \multicolumn{2}{|c|}{ With Consumption } & \multicolumn{2}{|c|}{ Without Consumption } & & & \\
\hline & $\mathbf{F}$ & $\%$ & $\mathbf{F}$ & $\%$ & $\mathbf{F}$ & $\%$ & \\
\hline Good & 27 & $37.5 \%$ & 10 & $13.9 \%$ & 37 & $51.4 \%$ & 0.003 \\
\hline Fair & 28 & $38.9 \%$ & 1 & $1.4 \%$ & 29 & $40.3 \%$ & \\
\hline Poor & 6 & $8.3 \%$ & 0 & $0 \%$ & 6 & $8.3 \%$ & \\
\hline Total & 61 & $84.7 \%$ & 11 & $15.3 \%$ & 72 & $100 \%$ & \\
\hline
\end{tabular}


ception, emotion and motivation, which functions to process external stimuli. ${ }^{11}$ Furthermore, it is presumed that 55 students do not consume the Fe tablet because they have low motivation and awareness, conversely reducing their ability and confidence to perceive stimuli from the outside. $^{12}$

In addition to the internal factors, consumption of Fe tablet in young women is also likely to be influenced by the lack of interest in its consumption, generally because the subjects claimed to not fall ill frequently, hence they presume this therapy is unimportant. The side effects resulting from ignoring this drug may include dizziness, nausea and vomiting. Furthermore, the abundance of iron fortified foods is also one of the contributors to the low consumption of Fe tablet in young women. ${ }^{7}$ This result is in accordance with function theory, based on the assumption that, changes in individual behavior, depends on their needs hence the stimulus needed is one that can be understood with respect to a person's desire. According to Katz, this attitude is motivated by individual needs. ${ }^{13,14}$ Behavior has an instrumental function, which drives people positively towards the object for their desires. It further functions as a defense manipulation, when engaged in an environment-as it is an expressive value from someone in response to something. ${ }^{14}$

These results support the research conducted on 64 female students in Public Senior High School 2 of Banguntapan Bantul, whose findings indicated no significant correlation between knowledge and consumption of Fe tablet during menstruation, as corroborated by a p-value of $0.321 .^{3}$ Furthermore, the results demonstrate no association between both variables, as evinced by $\mathrm{p}=0.857$. Their fairly similar level of knowledge was believed to be caused by the education level of the respondents as all were first-year students in the faculty.

\section{The Influence of Female adoles- cents' Attitude on Fe Consumption Behavior}

Concerning the attitudinal aspect, the study demonstrated that $51.4 \%$ of the 72 respondents were classified in the good category. Furthermore, 37 subjects, representing $37.5 \%$ of the total sample, however, do not consume the tablet and only $13.9 \%$ of the respondents do. From the analysis on the influence between attitudes and $\mathrm{Fe}$ tablet consumption, it is observed that $\mathrm{p}$ value $0.003<\alpha=0.05$, means there is significant influence between the two variables.

Based on the results, it was also found that 27 respondents $(37.5 \%)$ pose a good attitude, yet they do not take the tablets, which was likely due to the lack of the opportunity to obtain guidance on health education and counseling from counselorssupport from the teacher, family and friends. Furthermore, trust may affect the individual awareness of anemia that can ensue during menstruation, which interferes with their learning, concentration and reproduction. In this event therefore, adolescents can find the nearest health service, while at school this service can be rendered by the institutions' health service (also known as UKS). Conversely, at home, they communicate with their families, especially mother's as through this opportunity, they gain social support to be healthier by consuming Fe tablet properly.

The formation of attitudes represents a personal experience, driven by knowledge possessed, influence of other people, who are considered important, cultural instigates and mass media, educational and religious establishments as well as emotional factors substantially affect the formation of a person's attitude. ${ }^{15}$ Attitude of young women, denotes a view, however in this case, it is different from the knowledge of $\mathrm{Fe}$ tablet and the mindset when it comes to its consumption. Unlike character, knowledge alone does not play the role to trigger decisions because it does transform into an attitude if the theory is accompanied by the willingness to act. Furthermore, this notion is corroborated by the results, which uncovered that attitude is of great significance on the behavior to utilize Fe tablets. A good understanding encourages people to display characters that are in accordance with the awareness that has been obtained. Furthermore, the existing theory postulates that knowledge influences a person's attitude, hence a good understanding actualizes a favorable mindsets and vice versa. ${ }^{12-14}$ In this research, it is revealed that the majority high proportion of young women had great stance, which was because their enlightenment on Fe tablet is also exceptional, however, a positive level of understanding in an individual with good attitudes does not necessarily lead to good behavior.

Knowledge, beliefs and emotions play an important role, in determining a complete approach. ${ }^{13}$ The knowledge of $\mathrm{Fe}$ tablets encourages them to take it into consideration and further attempt to prevent anemia, caused by iron deficiency. This is however in line with this study, which indicates that the majority of respondents $(51.7 \%)$ are well-informed and a great number pose good attitude, as reported by $51.4 \%$ of the sample.

Behavior is the response/reaction of an individual to a stimulus, received from out- side or within thus it is a function of their environment and individual characteristics, which include variables, such as motives, values, traits, personalities and attitudes, which interact with each other and the environmental factors (which pose greater impact) in determining behavior. ${ }^{12,13,15}$ Furthermore, the provision of similar stimulus, instigates different response from each person, due to personalized decisions, therefore indicating that someone with a good level of knowledge and attitude does not necessarily show a great behavior, by simply consuming Fe tablet.

In addition, the results of this study also indicate some respondents with a good attitude and 10 of which, consume Fe tablet, who utilize it to avoid anemia. Previously, students of Public Senior High School 1 of Gorontalo city have received reproductive health education and counseling on blood tablets. With counseling from health workers, they are expected to gain good knowledge and attitude in its consumption as it is likely that young women have gained experience from the environment and family. Furthermore, they have also being influenced by others, considered important, including teachers and health workers Mass media, the internet and emotional statements also play vital role in building up an adolescents' believe on the intake of Fe tablet, which is expected to prevent anemia.

\section{Conclusions}

The research investigates the influence of knowledge and attitude of female adolescents towards $\mathrm{Fe}$ tablet consumption at Public Senior High School 1 of Gorontalo. The conclusion drawn is summarized as follow. There is no correlation between the knowledge of female students on their consumption behavior of blood tablets. There is a relationship between the attitudes of female students on their consumption behavior of Fe tablet. Schools are expected to provide female students with education on this medication in biology class, so as to enhance their knowledge of reproductive health.

\section{References}

1. Ilich-Ernst JZ, McKenna AA, Badenhop NE, et al. Iron status, menarche, and calcium supplementation in adolescent girls. The American Journal of Clinical Nutrition. 1998;68(4):880-7.

2. Sara WA, Indonesia KKR, Kendari PK. Pengetahuan Remaja Tentang Manfaat 
Tablet Fe Saat Menstruasi Di SMAN 1 Sampara Kabupaten Konawe Tahun 2017; 2017.

3. Sutanti Y, Briawan D, Martianto D. Suplementasi besi mingguan meningkatkan hemoglobin sama efektif dengan kombinasi mingguan dan harian pada remaja putri. Jurnal Gizi dan Pangan 2016;11(1).

4. Sridhar D, Gostin LO. Reforming the world health organization. Jama 2011;305(15):1585-6.

5. Kementerian Kesehatan Republik Indonesia. Laporan Nasional Riset Kesehatan Dasar (Rikesdas) Tahun 2010; 2010.

6. Kementerian Kesehatan Republik Indonesia. Riset Kesehatan Dasar 2013; 2013.

7. Mutmainnah EH, Mardiah SS, Astiriyani E. Pengaruh Pemberian Tablet Fe Terhadap Perubahan Kadar
Hb Pada remaja putri Di Pondok pesantren miftahul khoer tasikmalaya tahun 2018. Jurnal Kesehatan Bidkesmas Respati 2018;2(9):28-37.

8. Fikawati S, Syafiq A, Nurjuaida S. Pengaruh suplementasi zat besi satu dan dua kali per minggu terhadap kadar hemoglobin pada siswi yang menderita anemia. Jurnal Ilmiah Universa Medicina 2004;24(4):170.

9. World Health Organization. World Report on Disability 2011; 2011.

10. Indriani Y, Khomsan A, Sukandar D, Riyadi H, Zuraida R. Pengaruh Pemberian Zat Besi dan Asam Folat Dibandingkan dengan Mutivitamin dan mineral pada Pekerja Wanita Usia Subur di Agroindustri Nanas. Makara Seri Kesehatan 2013;17(1).

11. Notoatmodjo S. Kesehatan masyarakat. Jakarta: Rineka Cipta; 2007.

12. Muhamad Z, Hadi AJ, Yani A.
Pengetahuan Dan Sikap Remaja Putri Dengan Pencegahan Keputihan Di Mts Negeri Telaga Biru Kabupaten Gorontalo. Promotif: Jurnal

Kesehatan Masyarakat 2019;9(1): 9-19.

13. Notoatmodjo S. Ilmu Perilaku Kesehatan. Jakarta: Rineka Cipta. 2010;200:26-35

14. Muhamad Z, Sumarmi S. Factors Affecting the Incidence of Chronic Energy Deficiency among Pregnant Women Attending the Pulubala Community Health Centre. Indian Journal of Public Health Research \& Development 2018;9(11).

15. Rijal S, Bachtiar S. Hubungan antara Sikap, Kemandirian Belajar, dan Gaya Belajar dengan Hasil Belajar Kognitif Siswa. Jurnal Bioedukatika 2015;3(2): 15-20. 